\title{
Whey Protein-Carboxymethylcellulose Obtained by Complex Coacervation as an Ingredient in Probiotic Fermented Milk
}

\author{
Maria Elisa Caetano-Silva1, Caroline Dário Capitani2 ${ }^{*}$, Adriane Elisabete Costa Antunes ${ }^{2}$,

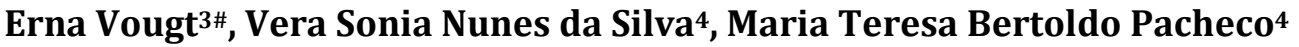 \\ ${ }^{1}$ Faculty of Food Engineering, University of Campinas, Campinas, Brazil \\ ${ }^{2}$ School of Applied Sciences, University of Campinas, Limeira, Brazil \\ ${ }^{3}$ Food Science and Technology Institute, Federal University of Rio Grande do Sul, Porto Alegre, Brazil \\ ${ }^{4}$ Chemistry Center of Food and Applied Nutrition, Institute of Food Technology (ITAL), Campinas, Brazil \\ Email: elisacaetano4@gmail.com, ${ }^{*}$ caroline.capitani@fca.unicamp.br, adriane.antunes@fca.unicamp.br, \\ vogt@ufrgs.br, mtb@ital.sp.gov.br
}

Received 24 February 2015; accepted 14 April 2015; published 16 April 2015

Copyright (C) 2015 by authors and Scientific Research Publishing Inc.

This work is licensed under the Creative Commons Attribution International License (CC BY).

http://creativecommons.org/licenses/by/4.0/

CC) (i) Open Access

\section{Abstract}

Discharge of whey proteins is still a current practice by small cheese producers. The development of low-cost alternatives for recovery of these proteins is fundamental for small producers who cannot apply expensive techniques. The present study investigated the complex coacervation technique as a cheap technology to recover proteins from sweet whey using carboxymethylcellulose, and the coacervate used as an ingredient in the formulation of probiotic fermented milk. The nutritional properties of whey-carboxymethylcellulose coacervates (WP-CMC) were evaluated in trials with animals (rats) using casein as a reference. All these parameters-the coefficient of feed efficiency (CEA), protein digestibility-corrected amino acid score (PDCAAS), and net protein ratio (NPR), as well as weight gain-were determined to evaluate protein quality. A sensory acceptance test was applied to evaluate the sensory characteristics of the product. The complex coacervation technique recovered $86 \%$ of the protein from sweet whey. No significant $(p>0.05)$ differences were observed in the biological tests for both groups (WP-CMC and Casein groups) when NPR (4.98 to 5.04), digestibility ( 92.35 to 90.64$)$, and CEA (0.40 to 0.42) were evaluated. Probiotic fermented milk beverage containing WP-CMC $(0.78 \%)$ and guar gum $(0.68 \%)$ presented good acceptability as determined by sensory evaluation. WP-CMC can be considered an ingredient with high nutritional and biological value that could be applied in probiotic fermented milk as an alternative to small producers to allocate the residual whey from cheese manufacture.

\footnotetext{
${ }^{*}$ Corresponding author.

${ }^{\#}$ In memoriam.
}

How to cite this paper: Caetano-Silva, M.E., Capitani, C.D., Antunes, A.E.C., Vougt, E., da Silva, V.S.N. and Pacheco, M.T.B. (2015) Whey Protein-Carboxymethylcellulose Obtained by Complex Coacervation as an Ingredient in Probiotic Fermented Milk. Food and Nutrition Sciences, 6, 571-580. http://dx.doi.org/10.4236/fns.2015.66060 


\section{Keywords}

\section{Nutritional Value, Whey Proteins, Complex Coacervation, Probiotic Fermented Milk, Environmental Impact}

\section{Introduction}

Whey is a residue from artisanal cheese production, and contains high organic load and hard biodegradability [1]. This by-product keeps almost 50\% from original milk nutrients [2], and its high-quality makes it an ideal ingredient for special formulations. Whey and its derivatives present effects on body composition, energy balance, satiety, and are indicated for use as fat substitutes in some industrialized foods [3].

Beside its high biological value, sweet whey has high water content $\left(0.9 \mathrm{~g}\right.$ protein $\left.\mathrm{L}^{-1}\right)$. The high volume of whey from cheese processing is still a problem for small industries and producers [4], and some techniques to protein recovery (ex. ultrafiltration, microfiltration, reverse osmosis, and ion-exchange) are impractical and have a high cost. The inadequate whey disposal leads to environment impacts due to its high biochemical oxygen demand (BOD) (30.000 - $60.000 \mathrm{mg}$ of $\mathrm{O}_{2} \cdot \mathrm{L}^{-1}$ ) [5]. Thus, some simple and classic techniques can be used by small dairy producers to transform whey into an attractive product with commercial value [1] [2].

The complex coacervation technique is a simple method to recover whey proteins and to reduce the environmental impacts [6]. Complex coacervation consists of spontaneous phase separation by forming an insoluble complex between two or more polymers as a result of electrostatic interactions [7]. The electrostatic interaction results in insoluble agglomerates, which precipitate spontaneously and can be easily separated from the aqueous medium by centrifugation [8]. Whey protein-polysaccharide coacervates by complex coacervation technique have been studied to promote protein recovery and may be applied to different types of foods and biomaterials (fat replacers, viscosity agents, coating and encapsulation). This interaction should be adapted and controlled to preserve or to improve the ingredient functionality and the final quality of the products [9].

Krzeminski et al. [10] studied the sensory and textural effects of WP-pectin complexes added to a low-fat yogurt matrix, when compared with a full-fat control. The authors demonstrated the ability of WP-high methoxyl pectin complexes to act as fat replacers and texturizing elements in reduced-fat yogurt. Capitani et al. [11] reported that carboxymethylcellulose coacervates (CMC), when complexed with whey proteins (WP), protected proteins against denaturation and increased their viscosity when gel systems were studied.

A combination of probiotics and whey protein concentrate (WPC) for use in yogurt production improved the growth and survival of the probiotic microorganisms L. acidophilus (LAC 4, Rhodia) and B. longum (BL, Rhodia), especially the former [12]. Fermented milk has several health benefits and is an excellent vehicle for the inclusion of functional ingredients, such as probiotic bacteria, dietary fiber, prebiotic carbohydrates, antioxidants, and other compounds [13].

Probiotics are defined as live microorganisms that, when administrated in adequate amounts, confer health benefits on the host [14]. Several factors have been reported to affect the viability of probiotics in fermented milk, including $\mathrm{pH}$, dissolved oxygen concentration, concentration of lactic acid and acetic acid, storage temperature, strains, and addition of whey protein [10].

Literature reports have demonstrated the physiological properties and technological applicability of whey proteins and whey proteins coacervated with polysaccharides. However, no reports are found on the nutritional quality and amino acids bioavailability of the polysaccharide coacervate proteins. The present study aims to evaluate both the nutritional and technological aspects of whey protein recovered by coacervation technique and its application in probiotic fermented milk.

\section{Material and Methods}

\subsection{Materials}

Sweet skimmed whey was obtained from a small-scale dairy (Espírito Santo do Pinhal, São Paulo, Brazil). Sodium carboxymethylcellulose (CMC) was obtained from Walocel CRT ${ }^{\mathrm{TM}} 40000$ PV (Dow Chemical Company, Brazil). Commercial casein was obtained from Naarden Agro Products. L-cysteine and choline bitartrate were 
purchased from Sigma (St. Louis, MO, USA). Bifidobacterium animalis supsp. lactis Bb-12 was kindly provided by Chr-Hansen/Brazil and Streptococcus thermophilus TA 40 by Danisco/Brazil.

\subsection{Preparation of WP-CMC Coacervate}

WP-CMC coacervate was obtained according to a previously described procedure [11] with some modifications. A flowchart with the main steps is shown in Figure 1.

An aqueous CMC solution $(0.3 \% \mathrm{w} / \mathrm{v})$ was stored overnight at $7^{\circ} \mathrm{C}$ to ensure complete hydration of the polymer to promote further interaction with whey proteins in solution. Initially, skimmed whey (WP) (adjusted to $\mathrm{pH}$ 3.0 using citric acid $10 \%)$ was mixed with the CMC solution $(0.3 \% \mathrm{w} / \mathrm{v})$, also adjusted to $\mathrm{pH} 3.0$, at a WP:CMC ratio of $1: 1(\mathrm{v} / \mathrm{v})$ and centrifuged at $2150 \times \mathrm{g}$ (SORVALL ${ }^{\circledR}$ RC-26 PLUS industrial scale centrifuge) at $22^{\circ} \mathrm{C}$. The coacervates (WP-CMC) were resuspended at $\mathrm{pH} 6.0$ with sodium carbonate $1 \mathrm{~mol} \cdot \mathrm{L}^{-1}$, and freeze-dried before use to evaluate their biological value and application as an ingredient in fermented milk.

\subsection{Chemical Composition of WP-CMC}

Protein (micro-Kjeldahl), moisture, ash and lipid contents were determined according to AOAC [15]. Residual lactose content in WP-CMC was determined by liquid chromatography, according to Burgner \& Feinberg [16]. All analysis was conducted in triplicate.

The amino acid levels were determined by high-performance liquid chromatography (HPLC) using a reverse phase column on a Shimadzu HPLC (Shimadzu Corporation, Japan) and UV detector at $254 \mathrm{~nm}$. The amino acids released by acid hydrolysis $\left(110^{\circ} \mathrm{C} / 22 \mathrm{~h}\right)$ were subjected to pre-column derivatization with phenyl isothiocyanate (PITC). Quantification was performed by internal calibration using amino butyric acid (AAAB) as standard [17], and based on a standard amino acid mixture (standard H/Pierce/P/N 20088). Amino acids analysis was conducted in duplicate.

\subsection{Protein Recovery and Complex Stability under Different $\mathrm{pH}$ Values}

After resuspension of WP-CMC in sodium carbonate to $\mathrm{pH}$ 6.0, protein recovery was measured by the following equation:

$$
\% \text { Protein recovery }=\frac{\text { Resuspended protein }}{\text { Initial protein }} \times 100
$$

In order to evaluate the effect of $\mathrm{pH}$ on complex stability, protein solubility was determined in the supernatant at different $\mathrm{pH}$ values. The WP-CMC coacervate solution was prepared using distilled water $\left(1 \mathrm{mg}\right.$ protein $\left.\mathrm{mL}^{-1}\right)$ and the $\mathrm{pH}$ value was adjusted to 2.0, 3.0, 4.0, 5.0, or 6.0, and kept under stirring for $30 \mathrm{~min}$. Then, samples were centrifuged at $2150 \times \mathrm{g}$ (SORVALL ${ }^{\circledR}$ RC-26 PLUS industrial scale centrifuge) for $30 \mathrm{~min}$ at $22^{\circ} \mathrm{C}$. The supernatants were evaluated for protein content by Micro-Kjeldahl method [15]. The percentage of soluble protein was calculated in relation to the initial protein content $\left(\mathrm{mg}\right.$ protein $\left.\mathrm{mL}^{-1}\right)$.

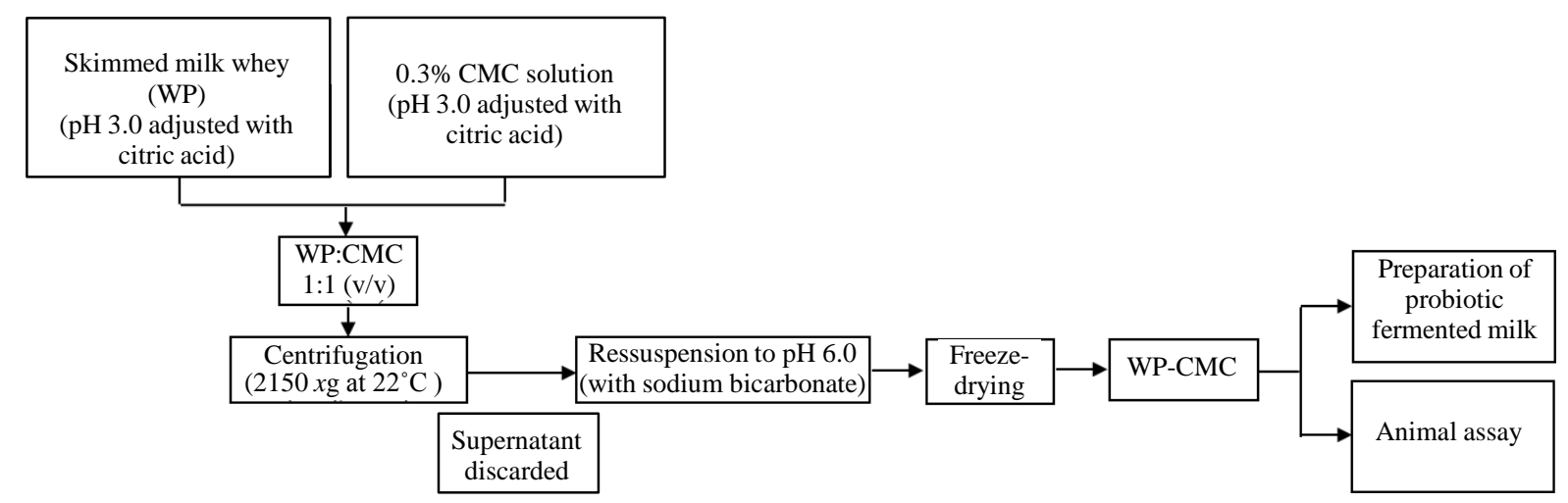




\subsection{Animals and Diets}

Male wistar rats $(n=21)$ with initial weight of $56.16 \pm 3.15 \mathrm{~g}$ were acclimated to standard housing conditions and fed on a $10 \%$ casein diet for 4 days. The $10 \%$ casein diet (Table 1 ) limits growth rate and allows differences in protein nutritional quality to be readily demonstrated [18].

Rats were then randomized according to weight into 3 groups (7 rats/group). The groups consumed ad libitum diets containing $10 \%$ protein consisting of Group 1-Casein (Control) or Group 2-WP-CMC coacervate (WP$\mathrm{CMC}$ ) for 14 days. The third group $(\mathrm{n}=7)$ was fed on a diet without protein during the same period (14 days) for determination of endogenous nitrogen loss. Apart from the protein content, nutrient levels of all diets were adequate for the growth of rats according to AING-95 [19]. Tap water, freely available for 14 days, was replaced daily during the study. Body weight and food consumption were measured every 3 days, and food consumption was corrected for spillage. Rats were placed in cages and fecal collections were made under clean-housing conditions to avoid mineral contamination. Samples were collected in acid-washed containers. All experiments were conducted according to The Code of Ethics of the World Medical Association (Declaration of Helsinki) and the Brazilian Regulations for animal experimentation (COBEA), after approval by Ethical Commission for Animal Experimentation at the University of Campinas (CEEA/ UNICAMP).

\subsection{Protein Nutritional Evaluation}

The coefficient of alimentary efficiency (CAE) of the complexes was calculated according to Osborne, Mendel, \& Ferry [20], by comparing the weight gain (WG) and the ingested protein (ID) in the experimental groups during 14 days. The CAE was calculated as follows: $\mathrm{CAE}=$ Weight gain/ID. The protein values of the WP-CMC coacervate were estimated using the net protein ratio (NPR) [18].

True protein digestibility (D\%) was determined as recommended by the Food and Agriculture Organization (FAO) [21] for in vivo testing. Feces were collected on the $14^{\text {th }}$ day of the experiment for nitrogen analysis. The amount of nitrogen consumed by the animals (I), the amount of nitrogen excreted in the feces of animals fed on a protein diet $(\mathrm{F})$, and the amount of nitrogen excreted in the feces of animals fed on a protein-free diet were used to calculate de protein digestibility as follow $(\% \mathrm{D}=$ endogenous nitrogen minus the amount of nitrogen excreted in the feces of animals fed on a protein-free diet $\times 100$ ).

PDCAAS was estimated by calculating the score of the most limiting essential amino acid [21]. A PDCAAS equal or greater than 1.0 indicates high-quality protein [22].

\subsection{Preparation of Probiotic Fermented Milk}

Initially, a sachet of freeze-dried probiotic culture Bifidobacterium animalis subsp. lactis Bb-12 (Chr-Hansen) was dissolved in $1 \mathrm{~L}$ of sterile whole milk, obtaining $3 \times 10^{9}$ colony forming units $\cdot \mathrm{mL}^{-1}\left(\mathrm{CFU} \cdot \mathrm{mL}^{-1}\right)$ of viable probiotic cells. The inoculated milk was transferred to sterile tubes $(10 \mathrm{~mL})$ and stored at $-18^{\circ} \mathrm{C}$. A culture of Streptococcus thermophilus (TA 40, kindly provided by Danisco) was previously dissolved in milk in the same way (Figure 2).

For manufacture of the fermented milk, commercial skim milk powder was dissolved in water at $10.00 \%$ $(\mathrm{w} / \mathrm{v})$, and $10.00 \%$ sugar, $0.78 \% \mathrm{WP}-\mathrm{CMC}$ coacervate, and $0.68 \%$ guar gum were added, according to the results obtained in a previous study [23]. Guar gum was added to minimize syneresis after fermentation.

The mixture was heat-treated at $85^{\circ} \mathrm{C}$ for $30 \mathrm{~min}$, and then cooled and inoculated with the probiotic bacteria and starter culture $(2.00 \%$ B. animalis and $1.00 \%$ S. thermophilus $)$, previously dissolved in sterilized milk, as described above. Fermentation was carried out at $45^{\circ} \mathrm{C}$ for approximately 4 hours until pH 4.6 was reached. At this point, $140 \mu \mathrm{L}$ strawberry flavoring (supplied by Symrise ${ }^{\circledR}$ ) and $50 \mu \mathrm{L}$ carmine colorant from cochineal (provided by Corantec ${ }^{\circledR}$ ) were added for each $100 \mathrm{~mL}$ product. The beverage was homogenized under a pressure of $70 \mathrm{Kgf} / \mathrm{cm}^{2}$ using an FT9 Armfield homogenizer, and kept under refrigeration at $8^{\circ} \mathrm{C} \pm 1^{\circ} \mathrm{C}$.

\subsection{Microbiological Analysis of Probiotic-Fermented Milk}

Microbiological analyses were carried out at the beginning and at the end of the storage period ( 3 and 28 days, respectively), according to the procedures recommended by the American Public Health Association [24]. The most probable number procedure (MPN) was used to determine coliforms at $35^{\circ} \mathrm{C}$ and $45^{\circ} \mathrm{C}$, using lauryl sulfate tryptose broth (LST from Difco) and brilliant green bile lactose broth (BGBLB from Difco), incubated at $35^{\circ} \mathrm{C} \pm$ $1{ }^{\circ} \mathrm{C}$ for 24 - $48 \mathrm{~h}$ for coliforms at $35^{\circ} \mathrm{C}$ [25], and using Escherichia coli broth (EC from Difco) incubated at $44^{\circ} \mathrm{C}$ 
Table 1. Ingredients, chemical composition, and energy value of diets used in the biological assay with male wistar rats.

\begin{tabular}{ccc}
\hline & Experimental data & \\
\hline Ingredients $(\mathbf{g})$ & Casein & WP-CMC \\
\hline Casein $\left(84.41 \%{ }^{\mathrm{a}}\right)$ & 118.47 & - \\
WP-CMC $\left(55.45 \%{ }^{\mathrm{a}}\right)$ & - & 180.34 \\
Saccharose & 100.00 & 100.00 \\
Soy oil & 70.00 & 70.00 \\
Fiber (cellulose) & 50.00 & 50.00 \\
Mineral mix (AIN-93G) & 35.00 & 35.00 \\
Vitamin mix (AIN-93G) & 10.00 & 10.00 \\
L-cistine & 3.00 & 3.00 \\
Choline bitartrate $(41.1 \%$ C) & 2.50 & 2.50 \\
Terc butyl hydroquinone & 0.014 & 0.014 \\
Cornstarch & 611.01 & 549.14 \\
Total & $\mathbf{1 0 0 0}$ & $\mathbf{1 0 0 0}$ \\
Energy (kcal/g) & 3.87 & 3.62 \\
\hline
\end{tabular}

${ }^{\mathrm{a}}$ Protein percentage.

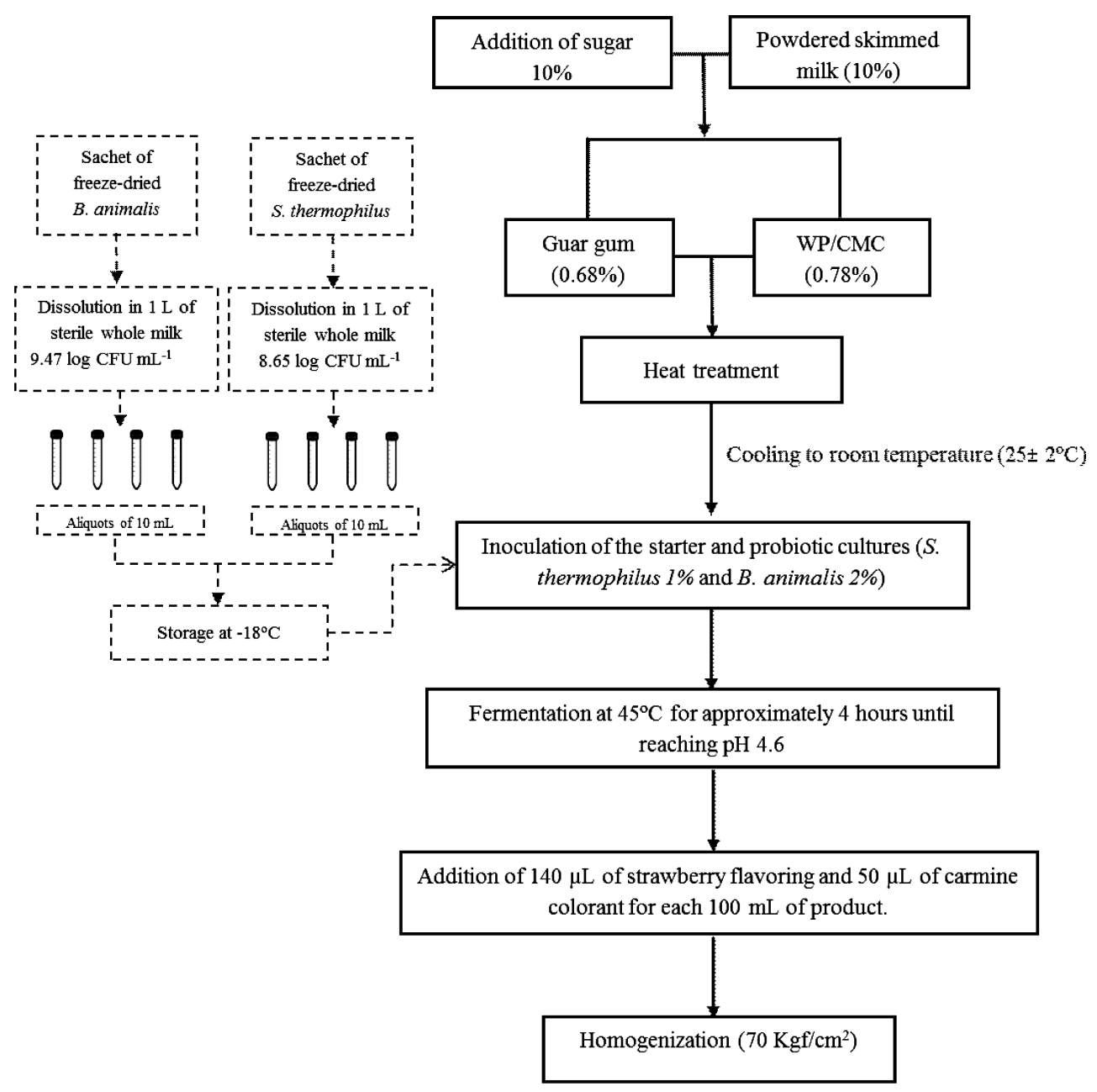

Figure 2. Preparation of probiotic fermented milk. 
$\pm 1^{\circ} \mathrm{C}$ for $24 \mathrm{~h} \mathrm{[26]} \mathrm{for} \mathrm{the} \mathrm{heat-tolerant} \mathrm{coliforms.} \mathrm{Dichloran} \mathrm{rose} \mathrm{bengal} \mathrm{chloramphenicol} \mathrm{agar} \mathrm{(DRBC} \mathrm{from}$ Difco) was used for yeast and mold counts, incubated at $25^{\circ} \mathrm{C} \pm 1^{\circ} \mathrm{C}$ for 5 days [27].

The viability of the $B$. animalis culture was determined using MRS Agar (Oxoid) supplemented with 0.5\% L-cysteine hydrochloride at $10.00 \%, 1.00 \%$ lithium chloride at $10.00 \%$ and $0.50 \%$ dicloxacillin at $0.10 \%$.

\subsection{Sensory Analysis}

Descriptive sensory analysis was carried out after 3 days of storage at $6^{\circ} \mathrm{C}$, by a group of 35 panelists (mean age 24 years) at the Sensory Laboratory of the Institute of Food Technology (ITAL/Campinas, Brazil). The research project was approved by the Ethics Committee for research in human beings of PUC-Campinas (n. 992/07), and all participants signed a term of consent. The overall acceptance was evaluated by the attributes appearance, consistency, taste, and overall impression, using a nine-point hedonic scale ( $9=$ extremely like, $5=$ neither like nor dislike, and 1 = extremely dislike). Sample were identified by a three random number code and served in plastic cups accompanied by natural mineral water for palate cleansing. The test was conducted in individual booths with fluorescent lighting and equipped with computerized Compusense Five version 4.8 for data collection and analysis.

\subsection{Statistical Analysis}

Analyses were performed in triplicate. Data were expressed as mean standard deviations (SD), and compared by analysis of variance (ANOVA) and Tukey's test. Statistical analysis was performed using the STATISTICA $12.0^{\circledR}$ software package for Windows (StatSoft, Inc., Tulsa, OK, USA). Differences were considered statistically significant at $\mathrm{p}<0.05$.

\section{Results and Discussion}

\subsection{Chemical Composition}

The chemical composition of the skimmed whey and the amino acid composition of the coacervate (WP-CMC) are described in Table 2.

As expected, proteins and lactose were the predominant components in WP-CMC and skimmed whey, respectively. As previously observed by Capitani et al. [11] using native PAGE-electrophoresis methodology, the complex coacervation with CMC was able to precipitate the total whey proteins (WP) in this work. A predominance of proteins (57.23\%) was observed in the WP-CMC coacervate in the conditions of this study. Thus, the complex coacervation technique was efficiently to separate proteins from sweet whey, presented concentrations of the essential amino acids above the recommendations for adults [28] and maintained the branchedchained amino acids (mg AA g protein ${ }^{-1}$ ) from sweet whey (Table 2).

\subsection{Protein Recovery and Coacervate Stability under Different pH Values}

The recovery of sweet whey proteins by complex coacervation was effective, since $86 \%$ proteins were recovered as protein-binding CMC polymers ( $\mathrm{pH} 3.5$ ), when compared to the initial composition.

The coacervate proteins remained insoluble in the range of $\mathrm{pH} 3.0$ to $\mathrm{pH}$ 6.0, as shown in Figure 3. Thus, the complexes did not dissociate at fermented milk $\mathrm{pH}(\mathrm{pH} 4.6)$, and remained aggregated as expected, which can have a positive effect on the final viscosity of the fermented milk.

\subsection{Body Weight Profiles and Diet Consumption}

All groups fed on the protein diets, except the non-protein group, presented a positive and linear tendency towards weight gain during the experimental period (14 days). No significant differences ( $p>0.05)$ were observed in weight gain, diet intake, and energy ingestion between the groups (Casein and WP-CMC Groups) (Table 3). Thus, the complex coacervation was effective for both protein recovery and maintenance of its biological value, since no difference in weight gain was observed when compared with the control (casein group).

Although similar growth and weight gain values were found for different protein sources in the experimental groups, a lower weight gain was observed in the WP-CMC ( 8.7\%) during 14 days, when compared to the Casein group. The Casein group consumed $1.43 \mathrm{~g}$ diet $\cdot \mathrm{day}^{-1}$, while the animals of the WP-CMC group consumed 
Table 2. Chemical composition of skimmed whey and WP-CMC (dry basis) and amino acids profile when compared to the WHO/FAO/UNU requirements and commercial casein.

\begin{tabular}{|c|c|c|c|}
\hline Component $\left(\mathrm{g} \cdot 100 \mathrm{~g}^{-1}\right)$ & Skimmed whey & \multicolumn{2}{|c|}{ WP-CMC ${ }^{a}$} \\
\hline Ash & $9.31 \pm 0.05$ & \multicolumn{2}{|c|}{$1.98 \pm 0.96$} \\
\hline Protein & $13.05 \pm 0.43$ & \multicolumn{2}{|c|}{$57.23 \pm 0.32$} \\
\hline Lipids & $0.89 \pm 0.05$ & \multicolumn{2}{|c|}{$9.42 \pm 0.00$} \\
\hline Lactose & $76.73 \pm 0.32$ & \multicolumn{2}{|c|}{$10.6 \pm 0.30$} \\
\hline Amino acid (AA) (mg AA g.protein $\left.{ }^{-1}\right)$ & Requirement pattern ${ }^{\mathrm{b}}$ & Casein & WP-CMC \\
\hline His & 19.0 & $35.1 \pm 0.4$ & $19.5 \pm 0.1$ \\
\hline Ile & 28.0 & $55.6 \pm 0.1$ & $51.2 \pm 0.1$ \\
\hline Leu & 66.0 & $119.9 \pm 0.5$ & $117.1 \pm 0.8$ \\
\hline Lys & 58.0 & $90.6 \pm 0.7$ & $82.1 \pm 0.5$ \\
\hline Met + Cys & 25.0 & $40.3 \pm 0.4$ & $40.6 \pm 0.6$ \\
\hline Phe + Tyr & 63.0 & $135.1 \pm 1.0$ & $70.7 \pm 0.5$ \\
\hline Thr & 34.0 & $52.9 \pm 0.1$ & $53.7 \pm 0.3$ \\
\hline Trp & 11.0 & $11.7 \pm 0.2$ & $13.0 \pm 0.7$ \\
\hline Val & 35.0 & $75.5 \pm 0.6$ & $58.5 \pm 0.2$ \\
\hline
\end{tabular}

${ }^{\mathrm{a}} \mathrm{WP}-\mathrm{CMC}=$ whey-carboxymethylcellulose coacervate; ${ }^{\mathrm{b}}$ Reference WHO [28].

Table 3. Weight gain, food and protein intake, net protein ratio (NPR), true digestibility (D), and protein digestibility-corrected amino acid score (PDCAAS) of rats fed on different experimental diets.

\begin{tabular}{ccc}
\hline & \multicolumn{2}{c}{ Diets } \\
\hline Parameter & Casein & WP-CMC \\
\hline Weight gain (g) & $48.21 \pm 4.20$ & $43.75 \pm 6.28$ \\
Total food intake (g) & $120.15 \pm 12.96$ & $103.46 \pm 14.70$ \\
Total protein intake (g) & $12.07 \pm 1.30$ & $10.88 \pm 1.53$ \\
NPR $^{\text {a }}$ & $5.01 \pm 0.26$ & $5.04 \pm 0.30$ \\
True Digestibility (\% D) & $92.35 \pm 1.01$ & $90.64 \pm 2.68$ \\
Food Efficiency (\% EF) & 0.40 & 0.42 \\
PDCAAS $^{\mathrm{c}}$ (\%) & 0.98 & 0.93 \\
\hline
\end{tabular}

${ }^{\mathrm{a} N P R}$ : Net Protein Ratio; 'PDCCAS: Protein Digestibility Corrected Amino Acid Score.

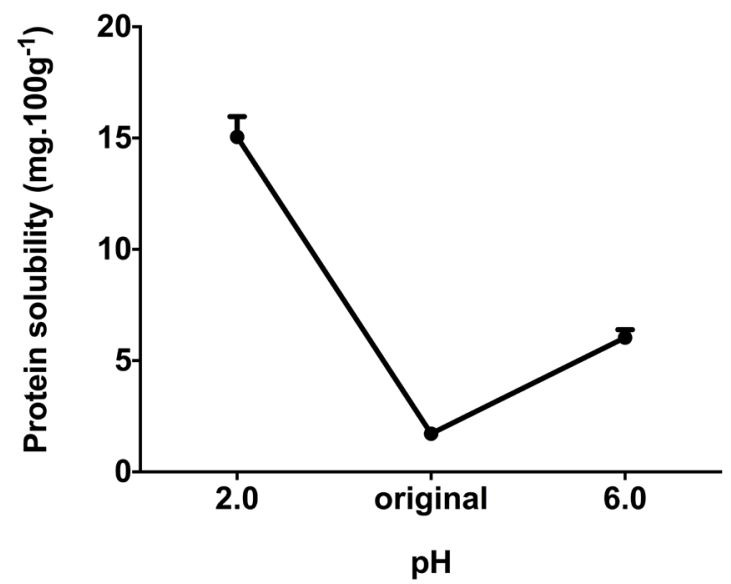

Figure 3. Solubility of protein from coacervates under different $\mathrm{pH}$ values. 
$1.23 \mathrm{~g}$ diet $\cdot$ day $^{-1}$. It is well known that polysaccharides can modify food texture and thus enhance product viscosity. The dissociation of WP-CMC during the digestion process, for example, can lead to polymer release. Therefore, the digestion process (at pH 2.0) may have contributed to the partial separation of the polymers, and the CMC, partially soluble or in the coacervated form may have contributed to satiety, reducing slightly diet intake in this group (WP-CMC).

However, future studies on adult animals should be carried out to evaluate others parameters such as blood glucose and cholesterol. This design would provide greater support for the discussion of the benefits of using whey proteins-CMC coacervate for weight gain and satiety, in addition to developing special food formulations.

\subsection{Nutritional Quality}

High true digestibility (D) and net protein ratio (NPR) values were observed for the protein in the coacervate products and casein, with no significantly $(p>0.05)$ differences between groups (Table 3$)$. The true digestibility is an important variable affecting the nutritional value of protein food, and commercial whey proteins have a high biological quality, when compared with casein. The present results showed high and adequate digestibility (D $>90 \%$ ) for all protein sources.

No statistical differences were observed in PDCCAS values $(p>0.05)$ for all groups (Table 3). These results demonstrate the high protein quality of the WP-CMC Coacervate (PDCAAS $\geq 1.0$ ). The PDCAAS method estimates protein quality, as it is capable of associating the essential amino acid doses with the true digestibility of the proteins. In other words, amino acids will be absorbed if proteins have high true digestibility, considering the most limiting amino acid of the chemical score. PDCAAS parameters and weight gain in experimental animals should be considered in infant formulas with high protein quality. Thus, the complex coacervation method may have efficiently maintained the biological value of the whey proteins [29].

It should be emphasized that complex coacervation is a process that principally involves electrostatic interactions, which are considered to be chemically weak [30]. The $\mathrm{pH}$ changes that occur during the digestion process may partially dissociate these complexes, increasing protein solubility and, consequently, its availability (Figure 3). Satisfactory weight gain and high-quality protein indicates a good availability of WP-CMC for digestion and utilization by normal metabolic pathways. In the conditions tested, the WP-CMC coacervate may be suitable for use as food ingredients with special characteristics, and can be applied in a fermented milk beverage, for example. For small dairy producers, it is a rapid and advantageous alternative, allowing protein recovery and its application in dairy products.

\subsection{Microbiological Analysis}

Microbiological analyses were carried out at the beginning and at the end of fermented milk storage (28 days). Counts lower than $3 \mathrm{NMP} \cdot \mathrm{mL}^{-1}$ for coliforms at $35^{\circ} \mathrm{C}$ and coliforms at $45^{\circ} \mathrm{C}$ were obtained in the beginning and at the end of the storage period. For mold and yeast counts, values lower than $10 \mathrm{UFC} \cdot \mathrm{mL}^{-1}$ were also observed in the fermented milk. Thus, the product presented appropriate microbiological quality according to the Brazilian legislation [31].

For a probiotic product to be marketed as presenting health-promoting benefits, it must present viable minimum probiotics count from $10^{8}$ to $10^{9} \mathrm{CFU}$ for a daily-consumption sized portion of the product [32], and the fermented milk produced in the present study attained this requirement $\left(8.44 \log \mathrm{CFU} \cdot \mathrm{mL}^{-1}\right)$. The application of whey protein coacervate in probiotic fermented milk was feasible and did not interfere with the B. animalis viability.

\subsection{Sensory Analysis}

The sensory evaluation of the probiotic fermented milk presented scores corresponding to "moderately like" for all attributes. Among the criteria used by consumers, the highest score $(7.3 \pm 1.1)$ was obtained for the attribute appearance, followed by consistency $(6.2 \pm 1.2)$, and overall impression $(6.0 \pm 1.6)$ on a 9-point hedonic scale. The beverage formulation could be altered according to the target public, especially with regard to flavor, since this attribute received the lowest score $(5.0 \pm 1.1)$. The use of coacervate allowed the preparation of a probiotic beverage, with protein of high biological value and good acceptability. 


\section{Conclusion}

Protein precipitation from sweet whey using complex coacervation with carboxymethylcellulose is an alternative to recover soluble proteins, being a rapid, efficient, low cost, and clean technique that allows small dairy producers to reuse whey from cheese manufacture. It is advantageous from the environmental point of view, since there is no discard, besides the enrichment of a fermented dairy beverage with a protein of high biological value, as observed in the experimental test. In addition, adequate probiotics viability in the probiotic fermented milk containing WP-CMC was observed. This study evidenced the potential of whey protein-carboxymethylcellulose coacervate as a low-cost strategy to recover sweet whey, which could be used to produce new ingredients for application in probiotic fermented dairy products.

\section{Acknowledgements}

The authors acknowledge financial support from Fundação de Amparo à Pesquisa de São Paulo (FAPESP) and CNPq for the scientific initiation scholarship.

\section{References}

[1] Araújo, M.S. (2013) Produção de etanol neutro a partir do soro de queijo coalho por destilação convencional. 70f, dissertação (mestrado), Centro De Ciências E Tecnologia Agroalimentar, Universidade Federal De Campina Grande, Pombal, Brasil.

[2] Oliveira, M.N. (2009) Tecnologia de Produtos Lácteos Funcionais/editora Maricê Nogueira de Oliveira. Atheneu Editora, São Paulo.

[3] Adjonu, R., Doran, G., Torley, P. and Agboola, S. (2013) Screening of Whey Protein Isolate Hydrolysates for Their Dual Functionality: Influence of Heat Pre-Treatment and Enzyme Specificity. Food Chemistry, 136, 1435-1443. http://dx.doi.org/10.1016/j.foodchem.2012.09.053

[4] Guedes, A.F.L.M., Machado, E.C.L., Fonseca, M.C., Andrade, S.A.C. and Stamford, T.L.M. (2013) The Use of Whey in the Formulation of Beverages with Fruits and Vegetables. Arquivo Brasileiro de Medicina Veterinária e Zootecnia, 65, 1231-1238. http://dx.doi.org/10.1590/S0102-09352013000400040

[5] Andrade, R.L.P. and Martins, J.F.P. (2002) Influência da adição da fécula de batata-doce (Ipomoea batatas L.) sobre a viscosidade do permeado de soro de queijo. Ciência e Tecnologia dos Alimentos, 22, 249-253. http://dx.doi.org/10.1590/S0101-20612002000300009

[6] Capitani, C.D., Pacheco, M.T.B., Gumerato, H.F., Vitali, A. and Schmidt, F.L. (2005) Milk Whey Protein Recuperation by Coacervation with Polysaccharide. Pesquisa Agropecuária Brasileira, 40, 1123-1128.

[7] Rocha-Selmi, G.A., Favaro-Trindade, C.S. and Grosso, C.R.F. (2013) Morphology, Stability, and Application of Lycopene Microcapsules Produced by Complex Coacervation. Journal of Chemistry, 2013, 7. http://dx.doi.org/10.1155/2013/982603

[8] Weinbreck, F., Nieuwenhuijse, H., Robijn, G.W. and de Kruif, C.G. (2004) Complexation of Whey Proteins with Carrageenan. Journal of Agricultural and Food Chemistry, 52, 3550-3555. http://dx.doi.org/10.1021/jf034969t

[9] Ye, A. (2008) Complexation between Milk Proteins and Polysaccharides via Electrostatic Interaction: Principles and Applications-A Review. International Journal of Food Science \& Technology, 43, 406-415. http://dx.doi.org/10.1111/j.1365-2621.2006.01454.x

[10] Krzeminski, A., Prell, K.A., Busch-Stockfischb, M., Weiss, J. and Hinrichs, J. (2014) Whey Protein-Pectin Complexes as New Texturizing Elements in Fat-Reduceded Yogurt Systems. International Dairy Journal, 36, 118-127. http://dx.doi.org/10.1016/j.idairyj.2014.01.018

[11] Capitani, C., Pérez, O.E., Pacheco, B., Teresa, M. and Pilosof, A.M.R. (2007) Influence of Complexing Carboxymethylcellulose on the Thermostability and Gelation of $\alpha$-Lactalbumin and $\beta$-Lactoglobulin. Food Hydrocolloids, 21, 1344-1354. http://dx.doi.org/10.1016/j.foodhyd.2006.10.022

[12] Antunes, A.E.C., Cazetto, T.F. and Bolini, H.M.A. (2005) Viability of Probiotic Micro-Organisms during Storage, Postacidification and Sensory Analysis of Fat-Free Yogurts with Added Whey Protein Concentrate. International Journal of Dairy Technology, 58, 169-173. http://dx.doi.org/10.1111/j.1471-0307.2005.00203.x

[13] Quirós, A., Ramos, M., Muguerza, B., Delgado, M.A., Miguel, M., Aleixandre, A. and Recio, I. (2007) Identification of Novel Antihypertensive Peptides in Milk Fermented with Enterococcus faecalis. International Dairy Journal, 17, 33-41. http://dx.doi.org/10.1016/j.idairyj.2005.12.011

[14] FAO/WHO (2001) Evaluation of Health and Nutritional Properties of Probiotics in Food Including Powder Milk with Live Acid Bacteria. Report of a Joint FAO/WHO Expert Consultation, Córdoba, Argentina. 
http://www.who.int/foodsafety/publications/fs_management/en/probiotics.pdf?ua=1

[15] Horwitz, W., Ed. (2010) Official Methods of Analysis of the Association of Official Analytical Chemists. In AOAC 18th Ed. 2005. Current through Revision 3, Gaithersburg.

[16] Burgner, E. and Feinberg, M. (1992) Determination of Mono- and Disaccharides in Foods by Interlaboratory Study: Quantitation of Bias Components for Liquid Chromatography. Journal of AOAC International, 75, 443-464.

[17] Hagen, S.R., Frost, B. and Augustin, J. (1989) Precolumn Phenylisothiocyanate Derivatization and Liquid Chromatography of Amino Acids in Food. Journal-Association of Official Analytical Chemists, 72, 912-916.

[18] Pellett, P.L. and Young, V.R. (1980) Nutritional Evaluation of Protein Foods. The United Nations University, Tokyo.

[19] Reeves, P.G., Rossow, K.L. and Lindlauf, J. (1993) Development and Testing of the AIN-93 Purified Diets for Rodents: Results on Growth, Kidney Calcification and Bone Mineralization in Rats and Mice. Journal of Nutrition, 123, 19231931.

[20] AOAC (1995) Official Methods of Analysis. 16th Edition, Association of Official Analytical Chemists, Washington.

[21] FAO/WHO/UNU (1991) Report of a Joint FAO/WHO Expert Consultation. Protein Quality Evaluation (FAO Food and Nutrition (Paper No. 51), FAO, Rome.

[22] Henley, E.C. and Kuster, J.M. (1994) Protein Quality Evaluation by Protein Digestibility Corrected Amino Acid Scoring. Food Technology, 48, 74-77.

[23] Caetano-Silva, M.E., Pacheco, M.T.B. and Antunes, A.E.C. (2010) Estudo da viabilidade tecnológica da aplicação de coacervado de proteínas de soro de leite com carboximetil celulose em iogurte probiótico. Brazilian Journal of Food Technology, 13, 30-37. http://dx.doi.org/10.4260/BJFT2010130100005

[24] APHA (2004) Standard Methods for the Examination of Dairy Products. 17th Edition, American Public Health Association, Washington.

[25] ISO 4831 (2006) Microbiology of Food and Animal Feeding Stuffs-Horizontal Method for the Detection and Enumeration of Coliforms-Most Probable Number Technique. 3rd Edition, The International Organization for Standardization, Geneva.

[26] ISO 7251 (2005) Microbiology of Food and Animal Stuffs-Horizontal Method for the Detection and Enumeration of Presumptive Escherichia coli-Most Probable Number Technique. 3rd Edition, The International Organization for Standardization, Geneva.

[27] ISO/IDF. ISO6611/IDF94 (2004) Milk and Milk Products—Enumeration of Colony-Forming Units of Yeast and/or Molds-Colony-Count Technique at $25^{\circ} \mathrm{C}$. Switzerland.

[28] FAO/WHO/UNU (2007) Expert Consultation on Protein and Amino Acid Requirements in Human Nutrition. WHO Technical Reports Series No 935, World Health Organization, Geneva.

[29] Food and Drug Administration/FDA (1996) Review of Infant Formula Requirements; Announcement of Study; Request for Scientific Data and Information; Announcement of Open Meeting. Federal Register, 61, 8628-8629.

[30] Tolstoguzov, V.B. (1998) Functional Properties of Protein-Polysaccharide Mixtures. In: Hill, S.E., Ledward, D.A. and Mitchell, J.R., Eds., Functional Properties of Food Macromolecules, Elservier, London, 252-277.

[31] Fermented Milks (CODEX STAN 243-2003) Codex Standard for Fermented Milks. In General Standard for the Labelling of Prepackaged Foods (CODEX STAN 1-1985) and the General Standard for the Use of Dairy Terms (CODEX STAN 206-1999).

[32] Brazilian Agency of Sanitary Surveillance. Food with Health Claims, New Foods/Ingredients, Bioactive Compounds and Probiotics. http://anvisa.gov.br/alimentos/comissoes/tecno lista alega.htm 